\title{
Efficacy of Pelletized Lime versus Limestone Sand for Forest Regeneration Enhancement in Pennsylvania, USA
}

\author{
Nesha L. Mizel, William E. Sharpe, Bryan R. Swistock* \\ Penn State Institutes of Energy and the Environment and Department of Ecosystem Science and Management, \\ 308 Forest Resources Building, Pennsylvania State University, University Park, PA, USA \\ Email: ${ }^{*}$ brs@psu.edu
}

Received 6 January 2015; accepted 23 January 2015; published 27 January 2015

Copyright (C) 2015 by authors and Scientific Research Publishing Inc.

This work is licensed under the Creative Commons Attribution International License (CC BY). http://creativecommons.org/licenses/by/4.0/

(c) (;) Open Access

\begin{abstract}
The efficacy of limestone sand and pelletized lime for remediation of soil acidity was compared in order to determine if limestone sand was a more cost-effective alternative to pelletized lime. Between fall of 2002 and spring 2003, two forested sites in Pennsylvania were clear cut and fenced. Pelletized lime and limestone sand were applied to separate $400-\mathrm{m}^{2}$ plots within the sites at rates of $2170 \mathrm{~kg} \cdot \mathrm{ha}^{-1}$ and $4335 \mathrm{~kg} \cdot \mathrm{ha}^{-1}$, respectively. Two additional $400-\mathrm{m}^{2}$ plots were used as controls. A paired before-after control-impact study design was used to assess changes in soil, soil solution, vegetation and biomass after lime application. Soil samples were collected from the $\mathrm{Oi}, \mathrm{Oe}+\mathrm{Oa}$, and $A$ horizons before and after lime application. Woody and herbaceous vegetation was harvested from 1- $\mathrm{m}^{2}$ sub-plots before and after liming and bi-weekly soil solution samples were collected for six months following lime application. Analysis of variance procedures were used to compare changes in the treatment plots over time. Changes in soil chemistry following lime application were comparable on the limestone sand and pelletized lime plots. There was a significant increase in exchangeable $\mathrm{Mg}$ and $\mathrm{Mg}$ saturation in the $\mathrm{Oe}+\mathrm{Oa}$ horizon on all of the lime treatment plots relative to controls, but a greater percentage of applied Ca and Mg was exchangeable in the 0 -horizon in pelletized lime plots nine months after liming. Plant biomass did not increase on the lime treatment plots relative to the control one year post treatment. The majority of applied Ca and $\mathrm{Mg}$ from pelletized lime and limestone sand remained in the litter layer, with little movement into the A-horizon after one growing season. These results indicated that the application of limestone sand at two times the rate of pelletized lime produced comparable changes in soil and soil solution chemistry at a fraction of the cost.
\end{abstract}

\section{Keywords}

Forest Regeneration, Pelletized Lime, Limestone Sand, Soil, Soil Water

\footnotetext{
${ }^{*}$ Corresponding author.

How to cite this paper: Mizel, N. L., Sharpe, W. E., \& Swistock, B. R. (2015). Efficacy of Pelletized Lime versus Limestone Sand for Forest Regeneration Enhancement in Pennsylvania, USA. Open Journal of Forestry, 5, 221-234.

http://dx.doi.org/10.4236/ojf.2015.52020
} 


\section{Introduction}

The retention of base cations in the forest floor is critical to forest health and regeneration (Tomlinson \& Tomlinson, 1990). Acidic deposition and forest harvesting are both processes that may result in the export of base cations from terrestrial ecosystems, and a reduction in nutrient capital on forested watersheds. If severe enough, reduced soil fertility and increased acidity can limit forest growth, and eventually lead to a decline in acid sensitive tree species (Cronan \& Grigal, 1995; Hallett \& Hornbeck, 1997; Demchik \& Sharpe, 2000; Drohan et al., 2002). Forest liming may be used to increase base saturation in the soil, and to mitigate soil acidity (Schreffler \& Sharpe, 2003). Liming also may benefit forest productivity by limiting the solubility of aluminum (Al) and its exchange into soil solution, and by providing additional inputs of calcium (Ca) and magnesium (Mg) into the soil.

Liming has been shown to stimulate nitrification in the forest floor; consequently high concentrations of $\mathrm{NO}_{3}$ in the soil solution also have been identified as a negative effect of terrestrial liming (Geary \& Driscoll, 1996; Simmons et al., 1996). Since forest harvesting has also been associated with increased nitrification in the forest floor and excess $\mathrm{NO}_{3}$ leaching, the application of lime to remediate nutrient losses following forest harvesting has not been considered as a viable forest management technique (Simmons et al., 1996; De Keersmaeker et al., 2000). Lime application has also been shown to lead to an increase in $\mathrm{SO}_{4}$ concentrations in the soil solution (De Keersmaeker et al., 2000; Schreffler \& Sharpe, 2003). Increases in soil pH in the organic horizon that typically follow lime application decrease the positive charge of the soil surface, leading to a reduction in exchange sites for $\mathrm{SO}_{4}$, and an increase in $\mathrm{SO}_{4}$ concentrations in the soil solution (Bolan et al., 1988). Liming also has been shown to stimulate microbial mineralization of organic matter, resulting in $\mathrm{SO}_{4}$ mobilization (Marschner, 1993).

Terrestrial application of lime has been used to mitigate soil acidity and base cation losses resulting from nutrient uptake and harvesting of crops in agriculture for hundreds of years. The liming of forest ecosystems is a comparatively new restoration technique. Consequently, there is a lack of available field-based information regarding the costs and comparative benefits of forest liming, the transport and fate of lime in forested watersheds, and the comparative evaluation of liming materials and application techniques.

Aerial application of pelletized lime is frequently used in large-scale forest liming projects; however, this method of application is costly. The use of all-terrain spreading equipment could reduce cost of lime application significantly. All terrain ground spreading equipment developed for this project was capable of applying both pelletized limestone and limestone sand. Pelletized lime is of uniform particle size and dissolves rapidly. Limestone sand is of variable particle size $(<500 \mu \mathrm{mm}$ to $3 \mathrm{~mm}$ diameter), dissolves more slowly, is much less expensive, and is easier to handle in bulk applications than pelletized limestone. The objective of this study was to determine and compare the transport and fate of pelletized lime and limestone sand following forest harvesting at two sites in Pennsylvania.

\section{Materials and Methods}

\subsection{Site Descriptions}

During 2002 and 2003 two forested sites on the Appalachian Plateau in Pennsylvania were harvested: Mosquito Creek and Rolling Rock. The sites are located in northwestern and southwestern Pennsylvania, respectively. At Mosquito Creek, the soils are strongly acidic to extremely acidic Cookport Hazleton Clymer associations, weathered from shale and sandstone of the Pottsville Formation (Hallowich, 1988). Predominant hardwood seedlings on the study plots included red maple (Acer rubrum) and black cherry (Prunus serotina), while smaller numbers of northern red oak (Quercus rubra L.) and white oak (Quercus alba) seedlings also were present on the plots. Dominant herbaceous vegetation of the study plots included hayscented fern (Dennstaedtia punctilobula), and blueberry (Vaccinium spp.). This site was clearcut in spring/summer 2003 and enclosed by a 2.4-m high woven wire fence to exclude white tailed deer (Odocoileus virginianus).

The soils at Rolling Rock are strongly acidic Gilpin-Dekalb-Cavode associations over acid gray shale and siltstone (Taylor et al., 1968). An 8.1-ha block of timber was clearcut in the late summer and fall of 2002. The site also was fenced in April 2003 using 2.4-m high woven wire fencing. Dominant hardwood seedlings within this cut included red maple, and black cherry. Dominant herbaceous vegetation on the plots included common greenbrier (Smilax rotundifolia), dewberry (Rubus hispidus), and common blackberry (Rubus allegheniensis).

Daily maximum and minimum temperature data for Mosquito Creek and Rolling Rock were collected from 
the University Park and Allegheny County Airport climate stations respectively. Daily precipitation data was collected on-site from May 2004 through October 2004 using tipping bucket rain gages. Precipitation data from the nearby climate stations was used to supplement on-site data from November 2003 through April 2004.

\subsection{Liming Materials and Application}

Three $20 \mathrm{~m} \times 20 \mathrm{~m}$ study plots were randomly established at both sites: a control plot, a pelletized lime plot, and a limestone sand plot. Dolomitic (high Mg) pelletized lime ( $\sim 200$ per ton) and coarse dolomitic limestone sand (\$12 per ton) were applied by hand to the appropriate plots.

Pelletized lime is made by granulating fine agricultural lime. Small granular particles are bound together into small pellets, which are typically between 1 - 2-mm diameter, using a water-soluble lignosulfonate binder. Pellets are designed to disintegrate and return to a granulated powder form upon contact with moisture. The pelletized lime applied at Mosquito Creek and Rolling Rock was purchased from New Enterprise in Tyrone, PA.

Limestone sand is coarse material that is made by crushing limestone into smaller particles. Approximately $50 \%$ of limestone sand particles were $>2 \mathrm{~mm}$, and $25 \%$ were between 1 and $2 \mathrm{~mm}$ with the remainder consisting of smaller particles down to $<500 \mu \mathrm{m}$ diameter. The limestone sand applied at Mosquito Creek and Rolling Rock was purchased from the New Enterprise Stone and Lime quarry in Tyrone and Ashcom, PA, respectively.

The pelletized lime and limestone sand products from both quarries were analyzed for $\mathrm{Ca}, \mathrm{Mg}, \mathrm{Al}$ and manganese (Mn) content at The Materials Characterization Lab at Penn State University using a Leeman Labs PS3000UV Inductively Coupled Plasma Emission Spectrophotometer. Limestone sand applied at Mosquito Creek and Rolling Rock was $26 \%$ and $27 \% \mathrm{CaO}$ respectively, and $16.4 \%$ and $15.9 \%$ MgO respectively. Pelletized lime applied at Mosquito Creek and Rolling Rock was $25.7 \%$ and $27.4 \mathrm{CaO}$ respectively, and $16.2 \%$ and $14.8 \% \mathrm{MgO}$ respectively.

Lime application took place on September 27, 2003 at Rolling Rock, and on November 9, 2003 at the Mosquito Creek site. The pelletized lime and limestone sand products were applied to the plots at rates of 2170 $\mathrm{kg} \cdot \mathrm{ha}^{-1}$ and $4335 \mathrm{~kg} \cdot \mathrm{ha}^{-1}$ respectively. Both products were applied by hand following $20 \mathrm{~m}$ transects across each plot to ensure even distribution of the limestone sand and pelletized lime products $\left(454 \mathrm{~g} \cdot \mathrm{m}^{-2}\right.$ and $227 \mathrm{~g} \cdot \mathrm{m}^{-2} \mathrm{re}-$ spectively). These lime application rates were chosen 1) to hold costs to a level that would be practical for adoption of forest liming by forest management agencies; 2) to improve the base cation status of the limed soils and reduce $\mathrm{Al}$ toxicity based on previous experience and; 3) to likely produce comparable results between the two products since only a fraction of limestone sand particles are readily soluble compared to pelletized lime.

\subsection{Soil and Soil Solution Sampling and Analysis}

To determine the effect of the lime products on soil fertility, and to trace the movement of the products through the soil profile, soil samples were collected from the study plots prior to liming and approximately one year after liming. Three soil pits were excavated to a depth of 20 -cm in each $20 \mathrm{~m} \times 20 \mathrm{~m}$ plot, and samples were collected from the Oe $+\mathrm{Oa}$, A, and B soil horizons (3 replicates per horizon) and placed in zipperlock bags. Samples were delivered to the Agricultural Analytical Services Laboratory at The Pennsylvania State University for chemical analysis within 24 hours of collection. Sample analyses included $\mathrm{pH}$, acidity, exchangeable base cations (K, Mg, and $\mathrm{Ca}$ ), phosphorus (P), and cation exchange capacity (CEC). Soil $\mathrm{pH}$ was measured using a glass electrode and a 1:1 soil: water paste. Exchangeable base cations were measured using a Mehlich 3 extractant and inductively coupled plasma (ICP) analysis. CEC was calculated through the summation of exchangeable cations (Wolf \& Beegle, 1995). Soil samples from the Oe + Oa and A horizons were analyzed for total Ca and total Mg using a total sorbed metals test (acid digestion and ICP analysis) following EPA method 3050 (USEPA, 1986). Initial results for total $\mathrm{Ca}$ and $\mathrm{Mg}$ in the $\mathrm{Oe}+\mathrm{Oa}$ horizon of the limestone sand plots showed variances greater than mean $\mathrm{Ca}$ and $\mathrm{Mg}$ concentrations; consequently, three additional Oe + Oa horizon samples were collected for total Ca and total Mg analyses from both limestone sand plots in January 2005.

Soil solution samples were collected at the study plots to determine and compare the transport through the soil profile and biological availability of the two lime products over the growing season. Six soil water samplers were installed at each plot, three zero-tension at 5-cm depth, and three tension at 20-cm depth. Installation occurred during August 2003 at Mosquito Creek, and during the September 2003 at Rolling Rock.

Zero-tension samplers were constructed from polypropylene trays $(30 \times 28 \times 5 \mathrm{~cm})$ with 8-mm drainage outlets. The top $5 \mathrm{~cm}$ of the soil was removed in four intact blocks and placed inside the pan. Cheesecloth was 
placed over the outlets in the pans to facilitate drainage of soil water into the collection bottles, and to prevent the spouts from filling with soil (Swistock et al., 1990).

Tension samplers were constructed using 3.8-cm diameter PVC pipe and caps. Round bottom 5-cm diameter ceramic porous cups were purchased from Soil Moisture Equipment Corporation. Tension samplers were assembled following methods presented by Mitchell et al. (2001). A 10.5-cm diameter bucket auger was used to excavate 20-cm deep holes for the samplers. Wetted soil from the bottom of the holes was packed around the ceramic cup to ensure contact between the soil and the cup. Soil removed from the holes then was replaced and packed down around the samplers in the order that it was removed (Swistock et al., 1990).

The samplers were installed nine months prior to sampling to ensure adequate time for soil and soil water to return to pre-disturbance conditions (Shepard et al., 1990). Biweekly soil solution sampling was conducted from April through October 2004.Soil solution samples from the three samplers of each type at each depth were analyzed separately for the first three sampling periods to ensure that chemical analyses of tension and zero-tension samples at each plot were not significantly different. Samples from each depth were composited thereafter. To ensure that composited soil solution samples were representative at each plot, an equal volume of solution from each sampler was added when samples were composited.

Soil solution samples were analyzed for Al and Mn (Clesceri et al., 1998) at The Pennsylvania State Institutes of the Environment (PSIE) water laboratory. Samples were analyzed using a Perkin Elmer 5100 ZL Zeeman Furnace (3500A AA spectrometric method). Additional analyses were conducted at the US Forest Service's Timber and Watershed Laboratory in Parsons, West Virginia. Samples were analyzed for Ca, Mg, and potassium (K) using a Perkin Elmer Analyst 300 atomic absorption spectrophotometer (EPA methods 7140, 7450, and 7610, respectively). Nitrate $\left(\mathrm{NO}_{3}\right)$ and sulfate $\left(\mathrm{SO}_{4}\right)$ were measured using a Dionex Dx500 ion chromatograph (EPA method 300). The $\mathrm{pH}$ of the soil solution was measured electrometrically using a Fisher $915 \mathrm{pH}$ meter with combination electrode, following EPA method 150.1 (Edwards \& Wood, 1993).

\subsection{Vegetation Collection and Analysis}

Plant material was collected and analyzed in September 2003 before liming and in September 2004 after liming to determine whether changes in plant biomass and nutrient content occurred due to liming. Five 1 - $\mathrm{m}^{2}$ quadrats were randomly established in each plot using stratified random sampling methods. All of the vegetation rooted within the quadrat was harvested at the base of the stem, dried $\left(2\right.$ weeks, $\left.105^{\circ} \mathrm{C}\right)$, weighed, and ground using a Wiley Mill with a 1-mm screen. Leaf litter (Oi) and woody litter samples were collected from 900-cm² subplots within each quadrat, and leaf litter thickness was measured in each corner of the subplot. Woody litter included all twigs and small branches under 5-cm diameter. Vegetation, leaf and woody litter samples were sent to Agricultural Analytical Services at The Pennsylvania State University for chemical analysis. Samples were analyzed for analyzed for Ca, Mg, K, Mn, and Al with a Thermo Jerrell Ash 61E inductively coupled argon plasma emission spectrometer following the dry ash method (Miller, 1998).

\subsection{Calcium and Magnesium Mass Balance and Capital Estimation}

A mass balance of applied $\mathrm{Ca}$ and $\mathrm{Mg}$ was calculated to determine the fate of the lime products one growing season after application. The mass of $\mathrm{Ca}$ and $\mathrm{Mg}$ before and after liming was measured in the vegetation, and Oi, $\mathrm{Oe}+\mathrm{Oe}$, and A soil horizons. Increases in Ca and Mg masses were calculated by taking the difference between before- and after-liming measurements. Increases observed in control plots were subtracted from increases in the treatment plots and decreases in the control plots were added to treatment plots to account for natural changes. In addition, $\mathrm{Ca}$ and $\mathrm{Mg}$ mass data from all plots prior to liming were used to estimate $\mathrm{Ca}$ and $\mathrm{Mg}$ capital in the forest floor following forest harvesting.

The dry mass of the Oe + Oa horizon was estimated by removing the soil layer from three 400 - $\mathrm{cm}^{2}$ quadrats within each treatment plot. Samples were dried at $100^{\circ} \mathrm{C}$ for $48 \mathrm{hr}$ prior to weighing. The mass of soil in the A horizon in each plot was estimated using soil thickness and bulk density data collected from three points in each plot using the excavation method (Blake \& Hartge, 1986). All horizon sampling and mass calculations did not extend beyond 20-cm depth in the soil, since this was the lowest depth at which soil solution sampling occurred. Oi layer and vegetation dry mass per unit area were estimated using average masses calculated from sampling subplots (400- $\mathrm{cm}^{2}$ and $1 \mathrm{~m}^{2}$, respectively). The total mass of calcium and magnesium before and after liming then were calculated from the concentration and mass per unit area values. 


\subsection{Data Analysis}

A before-after, control-impact (BACI) study design was used for data collection and analysis. This design allowed us to account for pre-treatment differences existing among $20-\mathrm{m} \times 20$-m study plots, and to exclude other naturally occurring changes at the sites from our analysis of treatment effects. Analysis of variance (ANOVA) was used to analyze treatment effects on soil, vegetation and soil solution chemistry. Changes in soil and vegetation chemistry before and after liming were compared among the treatment and control plots. Significant treatment effects on soil and vegetation were determined through pairwise comparisons of changes in measured parameters in treatment plots with changes in control plots. Because soil solution samples were collected only after lime application, significant treatment effects on solution chemistry were determined using comparisons of parameter concentrations after liming between treatment and control plots. MiniTab, version 13.3 was used to conduct statistical analyses (MiniTab, 2000).

Data from Mosquito Creek and Rolling Rock were analyzed separately due to significant site differences. Oi layer concentration data and soil solution concentration data, excluding $\mathrm{pH}$ and $\mathrm{Ca} / \mathrm{Al}$ ratios, were log transformed to meet model assumptions of normality and equal variance. Because soil and vegetation samples were not taken from the same location before and after liming, changes in soil and vegetation chemistry were analyzed by subtracting mean sample concentrations before liming from individual sample concentrations after liming. Differences before and after liming were compared among treatment and control plots using Tukey's pairwise comparisons with a $90 \%$ confidence interval. Soil solution concentrations were analyzed using a fixed effects model that included treatment and time effects. Because soil solution samples were composited for the majority of the sampling period, it was not possible to use a repeated measures design. Statistical analyses of mass balance calculations, which included the increase in $\mathrm{Ca}$ and $\mathrm{Mg}\left(\mathrm{g} \cdot \mathrm{m}^{-2}\right)$ for soil and vegetation, were conducted using log-transformed masses of Ca and Mg.

\section{Results}

\subsection{Soil Treatment Effects}

Significant soil effects of both lime treatments were confined largely to the O-horizon at Mosquito Creek and Rolling Rock. The exchange capacity of the $\mathrm{O}$ horizon soil at both sites is quite large; consequently, movement of base cations out of this horizon is not expected to occur very rapidly. Changes to soil chemistry by limestone sand and pelletized lime were similar at Mosquito Creek, and those were similar to changes resulting from pelletized lime at Rolling Rock (Table 1). By contrast, changes in chemistry due to limestone sand at Rolling Rock were significantly different from responses observed in the other treatment plots. Total $\mathrm{Ca}$ and $\mathrm{Mg}$ in the Oi layer in-

Table 1. Mean Oe + Oa horizon chemistry before and after lime application at Mosquito Creek and Rolling Rock. Table lists $p$-values from pairwise comparisons between changes in soil chemistry after liming in treatment plots with changes in control plot.

\begin{tabular}{cccccccccc}
\hline & \multicolumn{3}{c}{ Pelletized Lime } & \multicolumn{3}{c}{ Limestone Sand } & \multicolumn{3}{c}{ Control } \\
\hline Mosquito Creek & Before & After & $p$-Value & Before & After & $p$-Value & Before & After \\
\hline pH & 3.9 & 4.23 & 0.106 & 3.83 & 4.33 & 0.045 & 4.16 & 3.9 \\
Ca/Al Ratio & 46.99 & 47.13 & 0.221 & 38.43 & 64.84 & 0.010 & 56.21 & 36.80 \\
Al & 2.03 & 2.29 & 0.263 & 2.63 & 1.79 & 0.009 & 2.02 & 2.99 \\
CEC & 24.53 & 35.06 & 0.097 & 24.73 & 35.66 & 0.086 & 25.16 & 25.26 \\
K (\% Saturation) & 4.1 & 3.06 & 0.108 & 4.36 & 2.3 & 0.043 & 3.06 & 3.36 \\
Rolling Rock & & & & & & & \\
pH & 3.96 & 4.90 & 0.169 & 3.96 & 4.86 & 0.184 & 4.13 & 4.06 \\
Ca/Al Ratio & 10.66 & 108.69 & 0.010 & 42.39 & 83.58 & 0.192 & 28.21 & 22.22 \\
Al & 7.35 & 1.10 & 0.000 & 4.73 & 1.75 & 0.034 & 4.62 & 3.74 \\
CEC & 21.2 & 40.80 & 0.000 & 26.90 & 25.83 & 0.999 & 22.96 & 21.93 \\
K (\% Saturation) & 2.90 & 2.43 & 0.103 & 2.03 & 2.20 & 0.490 & 2.70 & 3.46 \\
\hline
\end{tabular}


creased in both the limestone sand and pelletized lime plots at both sites. Pairwise comparisons showed significant increases of log-transformed $\mathrm{Ca}$ and $\mathrm{Mg}$ concentrations in the Oi layer in the treatment plots at Mosquito Creek and Rolling Rock $(p \leq 0.001)$. All of the limed plots experienced a significant increase in mean exchangeable Mg in the Oe + Oa horizon (Table 1). CEC increased significantly in the Oe + Oa horizon of all of the limed plots except the limestone sand plot at Rolling Rock. Increases in exchangeable Ca were observed in the Oe + Oa horizon of all of the limed plots except the limestone sand plot at Rolling Rock; however, only the increase in Ca following pelletized lime application at Rolling Rock was statistically significant (Table 1). Soil $\mathrm{pH}$ increased in the Oe + Oa horizon on all of the treatment plots; however, the change was not statistically significant. Mean K saturation decreased significantly following limestone sand and pelletized lime application at Mosquito Creek, and pelletized lime application at Rolling Rock (Table 1).

Pairwise comparisons between changes in Oe + Oa horizon chemistry following lime application showed limited differences between the lime treatments. At Mosquito Creek, limestone sand resulted in a significantly greater increase in $\mathrm{Ca} / \mathrm{Al}$ ratios compared to the pelletized lime treatment $(p=0.096)$. At Rolling Rock, mean exchangeable Ca and CEC showed a significantly greater increase following pelletized lime treatment compared to the limestone sand ( $p=0.009$ and $p=0.003$ respectively).

Mean $\mathrm{pH}, \mathrm{Ca} / \mathrm{Al}$ ratio, and exchangeable $\mathrm{Mg}$ decreased in the $\mathrm{Oe}+\mathrm{Oa}$ horizon of the control plot at Mosquito Creek between 2003 and 2004. At Rolling Rock, mean pH, Ca/Al ratio, exchangeable Ca and exchangeable Mg, and CEC decreased in the Oe + Oa horizon of the control plot (Table 1). However, only the decreases in $\mathrm{pH}$ observed at both sites were statistically significant, with $p=0.052$ and $p=0.004$ respectively.

Soil chemistry in the A horizon at Mosquito Creek and Rolling Rock did not exhibit a statistically significant treatment response. Total $\mathrm{Ca}$ and $\mathrm{Mg}$ in the A horizon did not show a significant response to either treatment; however, total Ca increased significantly over time on all plots at both sites $(p \leq 0.05)$. No significant treatment effects were observed in the B horizon at either site, which exhibited little to no change in soil chemistry.

\subsection{Soil Solution Chemistry Treatment Effects}

At Mosquito Creek, Ca concentrations in the soil solution did not respond significantly to limestone sand or pelletized lime application at 5- or 20-cm depth (Figure 1 and Figure 2). Conversely, Ca soil solution concentrations showed a response to both types of lime application for both soil depths at Rolling Rock (Figure 3 and Figure 4). The limestone sand application resulted in the greatest increase in Ca concentrations at both depths. Soil solution Ca concentrations at 5-cm depth may have been higher in the limestone sand plot at Rolling Rock compared to the limestone sand plot at Mosquito Creek because of much higher precipitation during the study and subsequently greater dissolution of limestone sand at Rolling Rock.

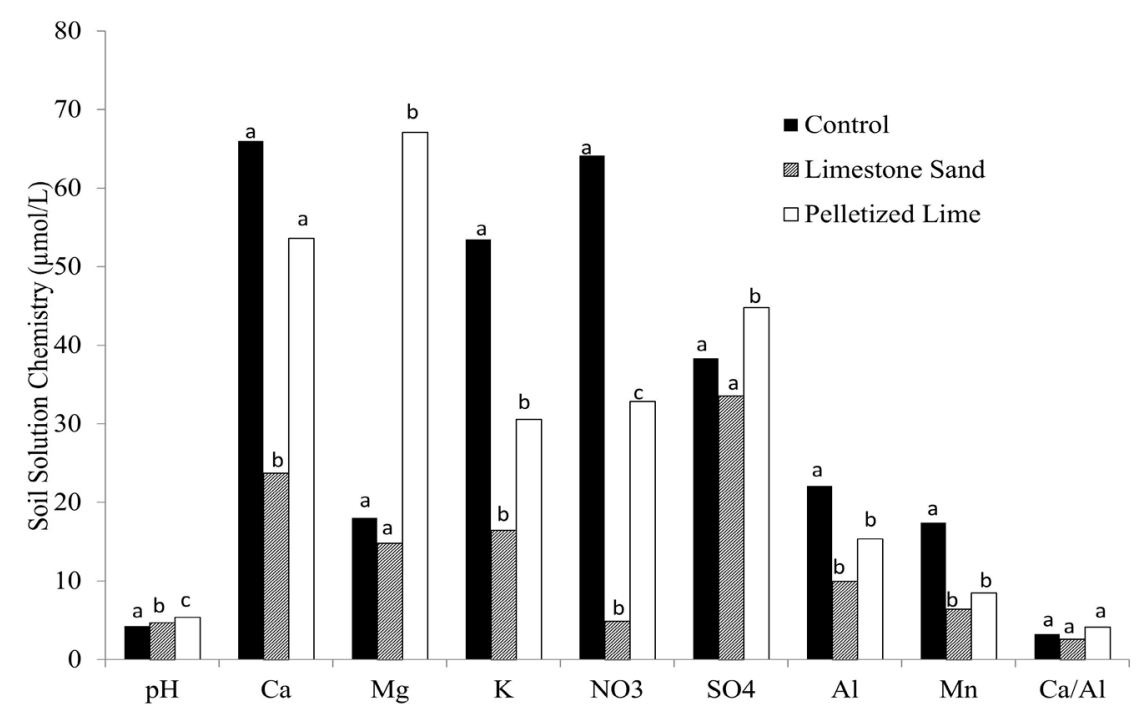

Figure 1. Comparison of mean soil solution chemistry $\left(\mu \mathrm{mol} \cdot \mathrm{L}^{-1}\right.$ except $\mathrm{pH}$ and $\mathrm{Ca} / \mathrm{Al}$ molar ratio) at the $5-\mathrm{cm}$ depth at the Mosquito Creek site between control, limestone sand and pelletized lime treatments. Letters above bars indicate statistically significant differences at $\alpha=0.05$. 


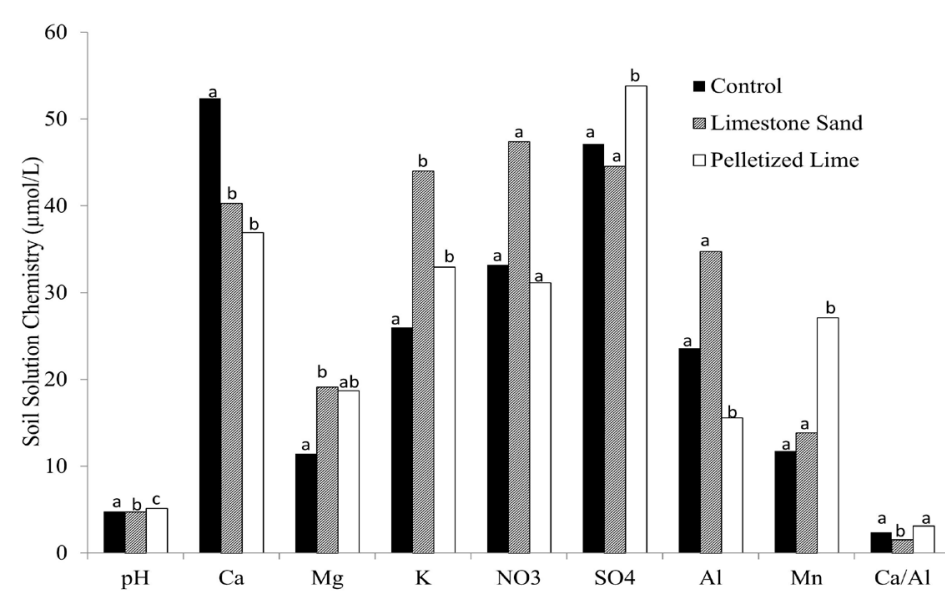

Figure 2. Comparison of mean soil solution chemistry ( $\mu \mathrm{mol} \cdot \mathrm{L}^{-1}$ except $\mathrm{pH}$ and $\mathrm{Ca} / \mathrm{Al}$ molar ratio) at the $20-\mathrm{cm}$ depth at the Mosquito Creek site between control, limestone sand and pelletized lime treatments. Letters above bars indicate statistically significant differences at $\alpha=0.05$.

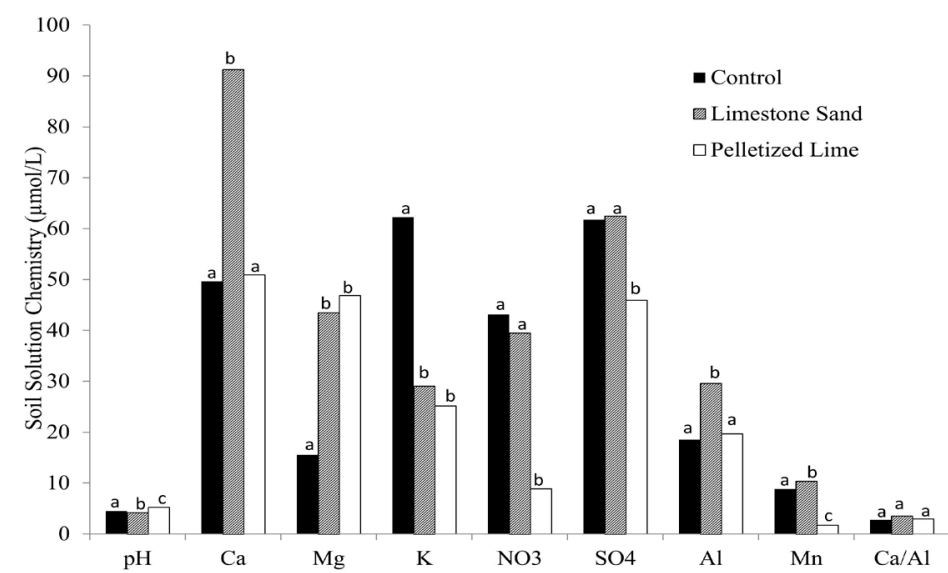

Figure 3. Comparison of mean soil solution chemistry ( $\mu \mathrm{mol} \cdot \mathrm{L}^{-1}$ except $\mathrm{pH}$ and $\mathrm{Ca} / \mathrm{Al}$ molar ratio) at the $5-\mathrm{cm}$ depth at the Rolling Rock site between control, limestone sand and pelletized lime treatments. Letters above bars indicate statistically significant differences at $\alpha=0.05$.

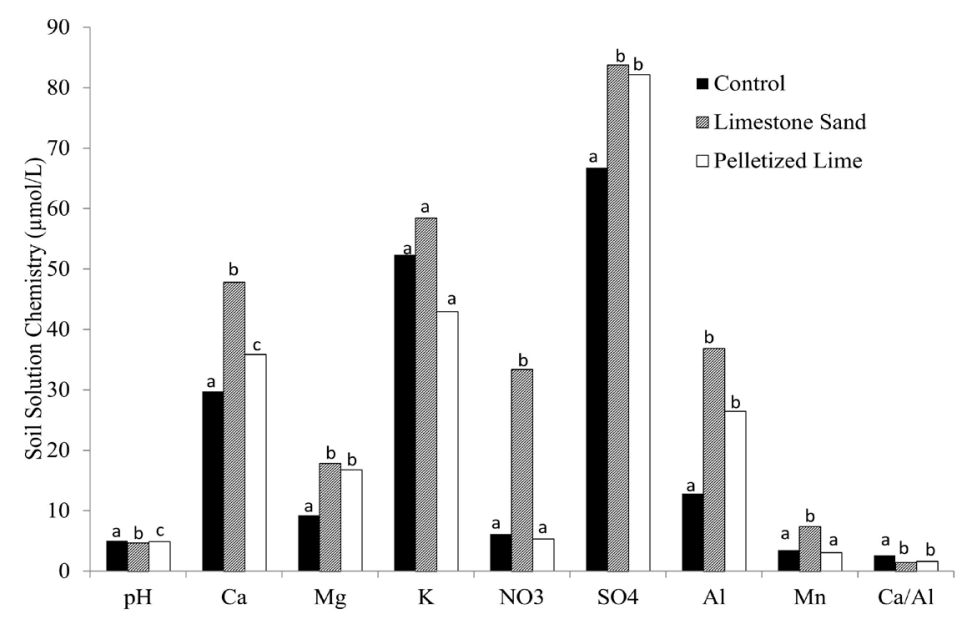

Figure 4. Comparison of mean soil solution chemistry ( $\mu \mathrm{mol} \cdot \mathrm{L}^{-1}$ except $\mathrm{pH}$ and $\mathrm{Ca} / \mathrm{Al}$ molar ratio) at the $20-\mathrm{cm}$ depth at the Rolling Rock site between control, limestone sand and pelletized lime treatments. Letters above bars indicate statistically significant differences at $\alpha=0.05$. 
At Mosquito Creek, Mg concentrations in soil solution at 5-cm depth were typically highest in the pelletized lime plot, while concentrations at 5-cm depth on the limestone sand plot were typically below the control (Figure 1). This trend was supported by statistical analysis, which showed that pelletized lime application resulted in a significantly greater increase in Mg concentrations compared to the limestone sand treatment. Mg concentrations at the 5-cm depth at Rolling Rock remained above concentrations in the control following limestone sand and pelletized lime application (Figure 3). Statistical analysis of Mg concentrations at 5-cm depth showed no significant difference between the two lime treatments at Rolling Rock. Mg concentrations in soil solution collected at 20-cm depth were higher in both limed plots than the control plots at both study sites (Figure 2 and Figure 4). There was no difference in Mg concentrations between the lime treatments at both sites.

$\mathrm{K}$ concentrations at both $5-$ and $20-\mathrm{cm}$ depths declined on all plots. This trend was supported by statistical analysis of $\log \mathrm{K}$ values from both Mosquito Creek and Rolling Rock, which were combined together by depth to determine changes over time ( $p<0.01$ at $5 \mathrm{~cm}, p \leq 0.000$ at $20 \mathrm{~cm}$ ). While there was no significant difference in soil solution $\mathrm{K}$ between the two treatments for either study site at 5 -cm depth (Figure 1 and Figure 3 ), the control had significantly higher K concentrations than the treatment plots. By contrast, at 20-cm depth at Mosquito Creek, K concentrations were significantly higher in both lime plots compared to the control plots (Figure 2). At Rolling Rock, there was no significant difference in $\mathrm{K}$ concentrations among the limed and control plots (Figure 4).

Mean soil solution $\mathrm{pH}$ was highest at 5- and 20-cm depth following pelletized lime application at both sites (Figures 1-4). Limestone sand application did not result in soil solution pH over 5 at either sampling depth at the study sites. At Mosquito Creek, mean $\mathrm{pH}$ at 5-cm depth on the limestone sand plot was significantly higher than the control. Conversely, mean $\mathrm{pH}$ at 20-cm depth was significantly lower than the control following limestone sand application at Mosquito Creek. Mean soil solution pH was significantly lower than the control at 5and 20-cm depth on the limestone sand plot at Rolling Rock.

Mean $\mathrm{NO}_{3}$ concentrations at 5-cm depth remained low in the limestone sand plot at Mosquito Creek throughout the growing season (mean $=0.158 \mathrm{mg} \cdot \mathrm{L}^{-1}$ ), while concentrations in the control plot were consistently higher than in either treatment plot. Neither lime treatment resulted in $\mathrm{NO}_{3}$ concentrations at 5-cm depth that were significantly greater than the control at both study sites (Figure 1 and Figure 3). At both Mosquito Creek and Rolling Rock, $\mathrm{NO}_{3}$ concentrations at 20-cm depth were highest on the plots treated with limestone sand at the beginning of the growing season. However, $\mathrm{NO}_{3}$ concentrations in the limestone sand plot at Mosquito Creek fell below the mean $\mathrm{NO}_{3}$ concentrations in both the pelletized lime and control plots at the end of August and remained below them. At Rolling Rock, mean $\mathrm{NO}_{3}$ concentrations at 20-cm depth were highest in the limestone sand plot throughout the growing season. There were no significant pairwise differences in soil solution mean $\mathrm{NO}_{3}$ at 20-cm depth between all plots at Mosquito Creek, but mean $\mathrm{NO}_{3}$ was significantly higher in the limestone sand plot at Rolling Rock than in the pelletized lime and control plots (Figure 3 and Figure 4).

Soil solution $\mathrm{SO}_{4}$ concentrations at Mosquito Creek were significantly higher in the pelletized lime than in the limestone sand and control plots at both 5- and 20-cm depths (Figure 1 and Figure 2). At Rolling Rock, SO was significantly lower in the pelletized lime treatment at the 5-cm depth compared to the other plots (Figure 3). At 20-cm depth, concentrations were significantly higher in both of the limed plots compared to the control, but the two treatments were not significantly different from one another (Figure 4).

At Mosquito Creek, $\mathrm{Al}$ concentrations at 5-cm depth were significantly higher in the control compared to the treatment plots, while there was no significant difference between the two lime treatments (Figure 1). At 20-cm depth, mean $\mathrm{Al}$ concentrations were highest in the limestone sand plot from May through early August, after which they dropped below the control through September. However, mean Al concentrations for the entire period were not significantly different between the limestone sand and control plots at 20-cm depth, but Al concentrations were significantly lower in the pelletized lime plot than the control and limestone sand plots at Mosquito Creek (Figure 2). Mean Al concentrations at Rolling Rock were highest in the limestone sand plot at both depths (Figure 3 and Figure 4). Al concentrations at 20-cm depth at Rolling Rock were significantly higher in both limed plots than in the control, while there was no significant difference in Al soil solution concentrations between the limestone sand and pelletized lime plots.

Pairwise comparisons of $\mathrm{Ca} / \mathrm{Al}$ ratios at 5-cm depth were not significantly different between any of the study plots at Mosquito Creek or Rolling Rock (Figure 1 and Figure 3). At Mosquito Creek, mean Ca/Al ratios in soil solution at 20-cm depth were highest in the pelletized lime plot (Figure 2). Mean Ca/Al ratios at 20-cm depth at Rolling Rock were significantly higher in the control plot than in both of the treatment plots (Figure 4). 
Mn concentrations at 5-cm depth were highest in the control plot at Mosquito Creek on all but one sampling date. At 5-cm depth in the pelletized lime plot at Rolling Rock they ranged from 0 to $0.1 \mathrm{mg} \cdot \mathrm{L}^{-1}$ throughout the sampling period. Mn concentrations in the limestone sand plot declined gradually throughout the growing season. By contrast, Mn concentrations in the limestone sand plots at 5-cm depth at Rolling Rock were significantly greater than both the control and pelletized lime plots (Figure 3). At 20-cm depth, results for the types of lime were essentially opposite one another at Mosquito Creek and Rolling Rock. Mn concentrations were highest in the pelletized lime plot at Mosquito Creek (Figure 2), while at Rolling Rock, concentrations were highest in the limestone sand plot (Figure 4).

\subsection{Vegetation Chemistry and Biomass Responses}

$\mathrm{Ca}$ and $\mathrm{Mg}$ concentrations decreased in the vegetation growing in control plots between 2003 and 2004 at both Mosquito Creek and Rolling Rock (Figure 5 and Figure 6). Ca concentrations increased in vegetation in both limed plots at both sites but was only significant in treatment plots at Mosquito Creek (Figure 5). Mg concen-

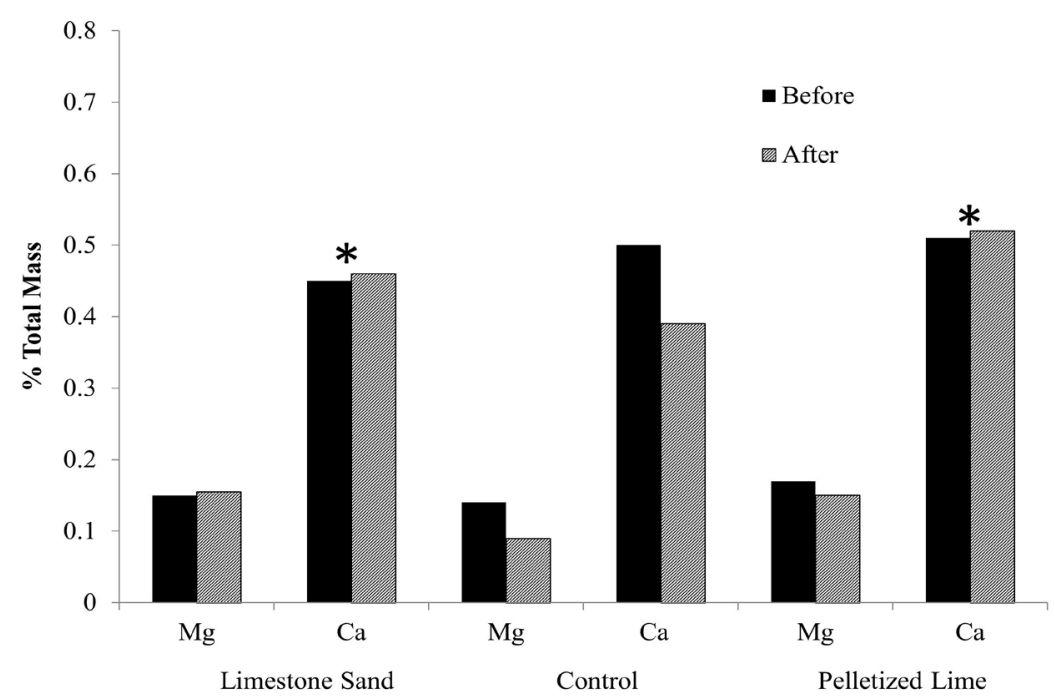

Figure 5. Mean vegetation calcium and magnesium (\%) before and after lime application at Mosquito Creek. The “*” above bars denotes a statistically significant difference at $p \leq 0.05$.

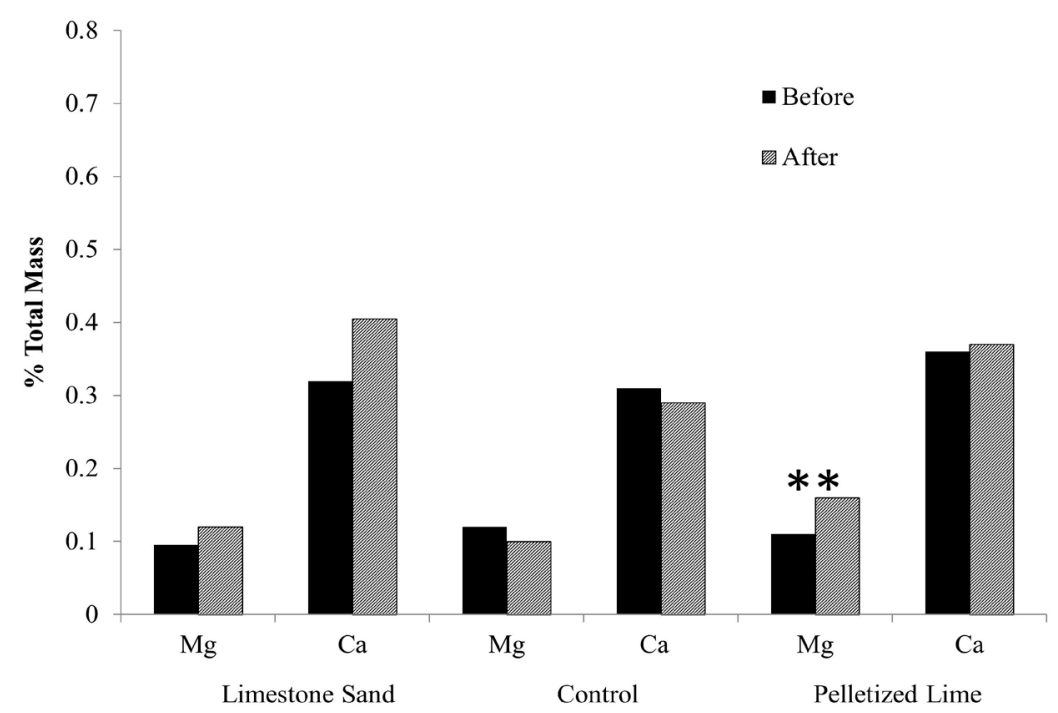

Figure 6. Mean vegetation calcium and magnesium (\%) before and after lime application at Rolling Rock. The “**” above bars denotes a statistically significant difference at $p \leq 0.10$. 
trations increased in all limed plots except for the pelletized lime plot at Mosquito Creek (Figure 5 and Figure 6). Mg concentrations increased in vegetation in the pelletized lime plot at Rolling Rock compared to the control.

K concentrations decreased significantly in vegetation between 2003 and 2004 in all plots at both Mosquito Creek and Rolling Rock ( $p \leq 0.005$, and $p \leq 0.000$, respectively). Pairwise comparisons showed no significant difference between decreases in K concentrations on treatment and control plots at both study sites. Liming did not significantly affect vegetation biomass. Vegetation biomass was highest in the limestone sand plots at both sites both before and one year after liming. Vegetation biomass increased in both control plots by 195\%. Vegetation in the pelletized lime plot at Rolling Rock had the smallest mean percent increase in biomass (148.91\%). Increases in vegetation Mg content observed at Mosquito Creek and Rolling Rock were not significantly correlated with greater increases in vegetation biomass.

\subsection{Mass Balance of Applied Calcium and Magnesium}

Mass balance calculations showed that 44\% to 78\% of Ca and $\mathrm{Mg}$ applied remained in the O-horizon of limed plots (Table 2). The standard deviations of mass balance estimates were very high as a result of high variance in total $\mathrm{Ca}$ and $\mathrm{Mg}$ in the upper soil horizons of limed plots. Statistical analysis of the distribution of applied Ca and $\mathrm{Mg}$ in the soil and vegetation on treatment plots showed few differences between $\mathrm{Ca}\left(\mathrm{kg} \cdot \mathrm{ha}^{-1}\right)$ and $\mathrm{Mg}$ $\left(\mathrm{kg} \cdot \mathrm{ha}^{-1}\right)$ values in the limestone sand and pelletized lime plots. At Mosquito Creek, mean $\mathrm{Mg}\left(\mathrm{kg} \cdot \mathrm{ha}^{-1}\right) \mathrm{was}$ significantly higher in the A-horizon of the pelletized lime plot compared to the limestone sand plot $(p \leq 0.10)$. Mean $\mathrm{Mg}\left(\mathrm{kg} \cdot \mathrm{ha}^{-1}\right)$ was significantly higher in the vegetation on the limestone sand plot at Rolling Rock when compared to the pelletized lime plot $(p \leq 0.10)$. The mass of Ca increased in the A-horizon of all study plots at Rolling Rock. Five to six percent of applied Ca on the limed plots at Rolling Rock moved into the A-horizon. By contrast, Mg did not increase in the A-horizon of either limed plot at Rolling Rock (Table 2).

\section{Discussion}

The results from this study demonstrated three major points:

1) Pelletized lime and limestone sand application were effective methods of mitigating Mg losses observed in the Oe + Oa horizon on control plots between 2003 and 2004. However, a greater percent of applied Ca and $\mathrm{Mg}$ from the pelletized lime was present in an exchangeable form in the soil about nine months after liming compared to limestone sand. Due to slow dissolution and high retention of $\mathrm{Ca}$ and $\mathrm{Mg}$ in the O-horizon, neither product increased base saturation or reduced acidity in the mineral soil during the first year of treatment. While this study did not specifically look at longer term impacts from the lime applications, Pabian et al. (2012), reported enhanced levels of $\mathrm{Ca}, \mathrm{Mg}$ and $\mathrm{Ca}$ : Al ratios, bird and snail abundance, and forb biomass five years after a similar application of limestone sand on an adjacent forest site.

Table 2. Mean (std. deviation) of applied calcium and magnesium in various compartments on limestone sand and pelletized lime plots at Mosquito Creek and rolling rock following liming.

\begin{tabular}{|c|c|c|c|c|}
\hline \multirow{2}{*}{$\begin{array}{c}\text { Mosquito Creek } \\
\text { Compartment }\end{array}$} & \multicolumn{2}{|c|}{ Calcium (\%) } & \multicolumn{2}{|c|}{ Magnesium (\%) } \\
\hline & Limestone Sand & Pelletized Lime & Limestone Sand & Pelletized Lime \\
\hline Leaf Litter (Oi) & 15.07 (7.08) & $22.03(25.56)$ & $14.28(6.77)$ & $22.08(19.40)$ \\
\hline Oe + Oa Horizon & $62.66(40.54)$ & 45.04 (51.49) & 60.03 (38.64) & $40.97(50.47)$ \\
\hline A-Horizon & $0.52(7.49)$ & 3.32(12.62) & $0.20(9.34)$ & 14.98 (71.47) \\
\hline Vegetation & $0.73(0.70)$ & $1.10(1.43)$ & $0.77(1.04)$ & $0.76(0.73)$ \\
\hline Missing & 21.02 (55.85) & $28.51(135.31)$ & $24.72(55.85)$ & 21.21 (150.88) \\
\hline \multicolumn{5}{|l|}{ Rolling Rock } \\
\hline Leaf Litter (Oi) & $3.26(3.45)$ & $18.01(26.90)$ & 3.48 (3.69) & $19.62(23.70)$ \\
\hline Oe + Oa Horizon & $40.80(40.72)$ & 54.43 (17.59) & 41.58 (32.03) & 38.13 (55.24) \\
\hline A-Horizon & $5.46(24.96)$ & $6.84(35.22)$ & 0.55 (9.23) & 0.31 (78.23) \\
\hline Vegetation & $1.43(1.65)$ & $0.11(1.80)$ & $0.95(0.86)$ & 1.07 (1.85) \\
\hline Missing & 49.05 (70.79) & 20.61 (81.52) & $53.44(45.81)$ & 40.87 (59.01) \\
\hline
\end{tabular}


2) Lime application did not significantly increase plant biomass on treatment plots compared to plant growth on the control plots. Large biomass increases would not be expected until woody stems became established on the plots and the presence of acid tolerant species on the study plots would indicate the potential for a poor initial response to base additions. Slow dissolution of the lime products and limited availability of applied Ca and $\mathrm{Mg}$ for plant uptake also may have limited vegetation growth responses to liming application. Consequently, several additional growing seasons would be required for growth changes to express themselves. Results from another similar study in this region (Pabian et al., 2012) showed substantial growth increases five years after liming. It is also possible that another nutrient may have been limiting plant growth at Mosquito Creek and Rolling Rock.

3) Pelletized lime and limestone sand treatments resulted in similar vertical distributions of applied Ca and Mg. The majority of applied $\mathrm{Ca}$ and $\mathrm{Mg}$ from pelletized lime and limestone sand remained in the litter layer, with little movement into the A-horizon. Greater leaching of applied Ca in the soil solution was observed at Rolling Rock presumably due to a thinner O-horizon, and greater amounts of precipitation at Rolling Rock during the study period. Mass balance calculations at Mosquito Creek showed evidence of greater downward transport of applied Mg on the pelletized lime plot, but due to large confidence intervals in distribution estimates, it is difficult to say that $\mathrm{Mg}$ derived from pelletized lime moved deeper into the soil.

Several other findings from this study are important to note. K saturation in the O-horizon was inversely related to $\mathrm{Ca}$ and $\mathrm{Mg}$ exchange, given that the greatest degree of $\mathrm{K}$ saturation was observed on the control plots at Mosquito Creek and Rolling Rock, and the limestone sand plot at Rolling Rock. The pattern of K concentrations in the soil solution observed at Mosquito Creek in control and treatment plots showed vertical leaching of $\mathrm{K}$ through the soil following liming. Lower concentrations of $\mathrm{K}$ in the soil solution at 5-cm depth in the limed plots may indicate that $\mathrm{Ca}$ and $\mathrm{Mg}$ exchange reactions occurring shortly after lime application reduced the amount of $\mathrm{K}$ in the O-horizon that could be easily leached. Higher $\mathrm{K}$ concentrations in treatment plots at 20-cm depth may be indicative of excess $\mathrm{K}$ leaching from the O-horizon, which could have begun shortly after lime application. Declines in K concentrations in the soil solution on all plots at Mosquito Creek and Rolling Rock throughout the growing season may indicate high demand for $\mathrm{K}$ by vegetation and soil biota. Consequently, additional application of $\mathrm{K}$ fertilizers may be necessary with forest liming to ensure adequate $\mathrm{K}$ nutrition.

Limestone sand application appeared to increase nitrification in the forest floor during the first half of the growing season when plant nutrient uptake increases rapidly. Similar results were not observed on the pelletized lime treatment plots, suggesting that the observed response was related to the different dissolution rates of the two products. Due to the faster dissolution rate of pelletized lime, it is possible that a similar peak in $\mathrm{NO}_{3}$ concentrations in the soil solution had occurred on the pelletized lime plots prior to the first sampling period. The rapid decline observed in soil solution $\mathrm{NO}_{3}$ concentrations in the limestone sand plots during the second half of the growing season indicated that plant and microbial demand for $\mathrm{N}$ may have increased, and/or nitrification in the soil may have decreased.

Elevated $\mathrm{SO}_{4}$ concentrations in soil solution were observed on both limed plots at Rolling Rock, where the mean increase in O-horizon $\mathrm{pH}$ was the greatest. At Mosquito Creek, soil solution $\mathrm{SO}_{4}$ concentrations in the pelletized lime plot were elevated above concentrations in the control. Differences in soil solution $\mathrm{SO}_{4}$ concentrations between the study sites could be explained by lower dissolution of limestone sand at Mosquito Creek and higher $\mathrm{SO}_{4}$ concentrations in the soil and soil solution at Rolling Rock prior to liming. Greater $\mathrm{SO}_{4}$ saturation in the soil is likely at Rolling Rock due to higher $\mathrm{SO}_{4}$ deposition at the site. According to Lynch (1999), $\mathrm{SO}_{4}$ deposition is highest in the western third of Pennsylvania where Rolling Rock is located, and decreases to the northeast toward the Mosquito Creek site. Mean $\mathrm{SO}_{4}$ concentrations in the control at Rolling Rock at 20-cm depth were almost 1.5 times greater than mean concentrations in the control at Mosquito Creek, suggesting that $\mathrm{SO}_{4}$ leaching was greater at Rolling Rock prior to lime application.

Both pelletized lime and limestone sand products appeared to be effective at increasing Ca and Mg concentrations in the vegetation at Rolling Rock, where concentrations on the control plots decreased. A similar response to treatment was observed in vegetation at Mosquito Creek; however, an increase in the mean $\mathrm{Mg}$ concentration of vegetation was not observed on the pelletized lime plot at Mosquito Creek despite a large amount of dissolution and movement of applied Mg. These results suggest that Mg may not have been limiting the growth of acid tolerant plants at this site. In addition, increases in vegetation biomass on the treatment plots at Mosquito Creek and Rolling Rock were not correlated with increases in $\mathrm{Ca}$ and $\mathrm{Mg}$ content in vegetation. The lack of correlation between Ca or Mg availability and plant concentrations, and the lack of plant growth responses may be ex- 
plained by plant species present at the study sites. Demchik and Sharpe (1998) found that red maple and blueberry had a negative response to Ca addition when measuring root elongation and these were two of the dominant species found at Mosquito Creek. Long et al. (1997) found that application of dolomitic lime did not affect growth of black cherry, which was dominant at both Rolling Rock and Mosquito Creek. In addition, methodology used to measure changes in nutrient content in vegetation were less sensitive to increases in Ca and $\mathrm{Mg}$ content because all plant biomass was included in the analysis, not just new growth following lime application. It is possible that, with time, additional species that favor soils with higher $\mathrm{Ca}$ and $\mathrm{Mg}$ will colonize these sites and yield a different response.

Cost is an important consideration for any large-scale forest liming project. Limestone sand and pelletized lime cost approximately \$12 per ton and \$200 per ton, respectively excluding equipment and labor. Both of these products were selected because each could be applied effectively in rough terrain with a commercially available log skidder especially modified for this purpose. In a much larger lime application on 800 acres at a nearby forest site, Pabian et al. (2012) found that limestone sand required much less effort to store and handle and was a very practical material for large scale forest revitalization activities.

\section{Conclusions}

Based on soil and soil solution chemistry on the control plots, both the Mosquito Creek and Rolling Rock, Pennsylvania sites appear to be nutrient poor sites with high soil acidity (Federer et al., 1989). It was expected that lime applications would serve to replace $\mathrm{Ca}$ and $\mathrm{Mg}$ losses resulting from soil acidification and forest harvesting at these sites.

Currently available ground spreading equipment may only be used to apply pelletized lime or limestone sand products due to clumping of fine powders that occurs in spreading equipment. Pelletized lime is currently about 17 times more expensive than limestone sand. Few terrestrial liming studies have investigated the efficacy of coarse lime materials (limestone sand). The results from this study indicated that, when applied at two times the rate of pelletized lime, limestone sand produced changes in soil and soil solution chemistry, and vegetation nutrient content comparable to pelletized lime, and thus, was a much more cost effective product than pelletized lime. Treatment effects were different between Rolling Rock and Mosquito Creek presumably due to pre-treatment site conditions; however, limestone sand increased exchangeable $\mathrm{Mg}$ and $\mathrm{Mg}$ saturation in the Oe + Oa horizon at both sites. Mosquito Creek had greater retention of applied $\mathrm{Ca}$ and $\mathrm{Mg}$ in the O-horizon, which was evident from significant increases in $\mathrm{pH}$, CEC, exchangeable $\mathrm{Ca}$ and the $\mathrm{Ca} / \mathrm{Al}$ ratio in the Oe + Oa horizon. Increases in $\mathrm{NO}_{3}$ and $\mathrm{SO}_{4}$ concentrations in soil solution did not appear to be excessive following application of either product. Due to the shallow rooting depth of tree seedlings, the significant treatment response observed in the O-horizon may give acid-sensitive tree species a greater opportunity for establishment and survival.

Both Mosquito Creek and Rolling Rock showed evidence of dissolution of the limestone sand product that was substantial enough to create conditions similar to those observed on the pelletized lime plots approximately nine months after lime application. Limestone sand dissolved rapidly even though the average sized particle was greater than the pelletized lime, both before and after pelletized lime had disintegrated into a fine powder upon contact with moisture. It is likely that the finest fraction of limestone sand particles dissolved and was present in the soil solution.

Dominant vegetation at the study sites was not highly sensitive to soil acidity; consequently, a significant increase in plant biomass following lime application was not observed on any of the treatment plots. We hypothesize that liming may increase plant biomass following the remediation of soil acidity, which would allow for the establishment of more acid-intolerant woody plant species. Results from soil solution and vegetation chemistry indicated that K concentrations declined on the study sites between 2003 and 2004. Lime application can exacerbate K leaching as a result of Ca antagonism; consequently, it may be desirable to apply K fertilizers with lime.

\section{Acknowledgements}

Research support for this study was provided by the Richard King Mellon Foundation, with in-kind support from the U.S.D.A. Forest Service Timber and Watershed Laboratory. We would like to thank Dr. Pamela Edwards, Fredrica Wood, John Pearce, and Lynda Gerath (USFS, Parsons, WV), who devoted a great deal of their time and support to this research. 


\section{References}

Blake, G. R., \& Hartge, K. H. (1986). Bulk Density, Methods of Soil Analysis, Part 1. Soil Science Society of America Journal, 363-376.

Bolan, N. S., Syers, J. K., Tillman, R. W., \& Scotter, D. R. (1988). Effect of Liming and Phosphate Additions on Sulfate Leaching in Soils. Journal of Soil Science, 39, 493-504. http://dx.doi.org/10.1111/j.1365-2389.1988.tb01234.x

Clesceri, L. S., Greenberg, A. E., \& Eaton, A. D. (Eds.) (1998). Standard Methods for the Examination of Water and Wastewater (20th ed.). American Public Health Association, American Water Works Association and Water Environment Federation, Washington DC.

Cronan, C. S., \& Grigal, D. F. (1995). Use of Calcium/Aluminum Ratios as Indicators of Stress in Forest Ecosystems. Journal of Environmental Quality, 24, 209-226. http://dx.doi.org/10.2134/jeq1995.00472425002400020002x

De Keersmaeker, L., Neirynck, J., Maddelein, D., De Schrijver, A., \& Lust, N. (2000). Soil Water Chemistry and Revegetation of a Limed Clearcut in a Nitrogen Saturated Forest. Water, Air, and Soil Pollution, 122, 49-62. http://dx.doi.org/10.1023/A:1005238213656

Demchik, M. C., \& Sharpe, W. E. (1998). The Effect of Calcium/Aluminum Ratio on Root Elongation of Twenty-Six Pennsylvania Plants. Proceedings of the 1998 PA Acidic Deposition Conference on the Effects of Acidic Deposition on Pennsylvania's Forests, The Pennsylvania State University, University Park, PA, 211-217.

Demchik, M. C., \& Sharpe, W. E. (2000). The Effect of Soil Nutrition, Soil Acidity and Drought on Northern Red Oak (Quercus rubra L.) Growth and Nutrition on Pennsylvania Sites with High and Low Red Oak Mortality. Forest Ecology and Management, 136, 199-207. http://dx.doi.org/10.1016/S0378-1127(99)00307-2

Drohan, P. J., Stout, S. L., \& Petersen, G. W. (2002). Sugar Maple (Acer saccharum Marsh.) Decline during 1979-1989 in Northern Pennsylvania. Forest Ecology and Management, 170, 1-17. http://dx.doi.org/10.1016/S0378-1127(01)00688-0

Edwards, P. J., \& Wood, F. (1993). Field and Laboratory Quality Assurance/Quality Control Protocols and Accomplishments for the Fernow Experimental Forest Watershed Acidification Study. USDA General Technical Report, NE-177.

Federer, C. A., Hornbeck, J. W., Tritton, L. M., Martin, C. W., Pierce, R. S., \& Smith, C. T.(1989). Long-Term Depletion of Calcium and Other Nutrients in Eastern US Forests. Environmental Management, 13, 593-601. http://dx.doi.org/10.1007/BF01874965

Geary, R. J., \& Driscoll, C. T. (1996). Forest Soil Solutions: Acid/Base Chemistry and Response to Calcite Treatment. Biogeochemistry, 32, 195-220. http://dx.doi.org/10.1007/BF02187139

Hallett, R. A., \& Hornbeck, J. W. (1997). Foliar and Soil Nutrient Relationships in Red Oak and White Pine Forests. Canadian Journal of Forest Research, 27, 1233-1244. http://dx.doi.org/10.1139/x97-026

Hallowich, J. S. (1988). Soil Survey of Clearfield County Pennsylvania. Soil Conservation Service, US Department of Agriculture.

Long, R. P., Horsley, S. B., \& Lilja, P. R. (1997). Impact of Forest Liming on Growth and Crown Vigor of Sugar Maple and Associated Hardwoods. Canadian Journal of Forest Research, 27, 1560-1573. http://dx.doi.org/10.1139/x97-074

Lynch, J. A. (1999). Atmospheric Deposition in Pennsylvania. Proceedings of the 1998 PA Acidic Deposition Conference on the Effects of Acidic Deposition on Pennsylvania's Forests, University Park, 245-257.

Marschner, B. (1993). Microbial Contribution to Sulfate Mobilization after Liming an Acid Forest Soil. Journal of Soil Science, 44, 459-466. http://dx.doi.org/10.1111/j.1365-2389.1993.tb00468.x

Miller, R. O. (1998). High-Temperature Oxidation: Dry Ashing. In Y. Kalra (Ed.), Handbook and Reference Methods for Plant Analysis. New York: CRC Press.

MiniTab for Windows (2000). Version 13.3. MiniTab Inc.

Mitchell, M. J., McGee, G., McHale, P., \& Weathers, K. C. (2001). Experimental Design and Instrumentation for Analyzing Solute Concentrations and Fluxes for Quantifying Biogeochemical Processes in Watersheds. Proceedings of the 4th International Conference in Long Term Ecological Research (LTER) in East Asian and Pacific Region, Lake Hovsgol, 2-5 July 2001.

Pabian, S. E., Rummel, S. M, Sharpe, W. E., \& Brittingham, M. C. (2012). Terrestrial Liming as a Restoration Technique for Acidified Forest Ecosystems. International Journal of Forestry Research, 2012, Article ID: 976809.

Schreffler, A. M., \& Sharpe, W. E. (2003). Effects of Lime, Fertilizer, and Herbicide on Forest Soil and Soil Solution Chemistry, Hardwood Regeneration, and Hardwood Growth Following Shelterwood Harvest. Forest Ecology and Management, 177, 471-484. http://dx.doi.org/10.1016/S0378-1127(02)00452-8

Shepard, J. P., Mitchell, M. J., Scott, T. J., \& Driscoll, C. T. (1990). Soil Solution Chemistry of an Adirondack Spodosol: Lysimetry and N Dynamics. Canadian Journal of Forest Research, 20, 818-824. http://dx.doi.org/10.1139/x90-108

Simmons, J. A., Yavitt, J. B., \& Fahey, T. J. (1996). Watershed Liming Effects on the Forest Floor N Cycle. Biogeochemistry, 32, 221-244. http://dx.doi.org/10.1007/BF02187140 
Swistock, B. R., Yamona, J. J., De Walle, D., \& Sharpe, W. E. (1990). Comparison of Soil Water Chemistry and Samples Size Requirements for Pan vs. Tension Lysimeters. Water Air Soil Pollution, 50, 387-396. http://dx.doi.org/10.1007/BF00280637

Taylor, D. C., Churchill, N. J., Losche, C. K., Mentzer, S. D., \& Weaver, J. B. (1968). Soil Survey of Westmoreland County Pennsylvania. Soil Conservation Service, US Department of Agriculture, USA.

Tomlinson, G. H., \& Tomlinson, R. L. (Eds.) (1990). Effects of Acid Deposition of the Forests of Europe and North America. Boca Raton, FL: CRC Press, Inc.

USEPA (1986). Test Methods for Evaluating Solid Waste (Volume IA, 3rd ed.). EPA/SW-846, Springfield, VA: National Technical Information Service.

Wolf, A. M., \& Beegle, D. B. (1995). Recommended Soil Tests for Macronutrients: Phosphorous, Potassium, Calcium and Magnesium. In T. J. Sims, \& A. Wolf (Eds.), Recommended Soil Testing Procedures for the Northeastern United States: Northeast Regional Bulletin \#493 (pp. 25-34). Newark, DE: Agricultural Experiment Station, University of Delaware. 
Scientific Research Publishing (SCIRP) is one of the largest Open Access journal publishers. It is currently publishing more than 200 open access, online, peer-reviewed journals covering a wide range of academic disciplines. SCIRP serves the worldwide academic communities and contributes to the progress and application of science with its publication.

Other selected journals from SCIRP are listed as below. Submit your manuscript to us via either submit@scirp.org or Online Submission Portal.
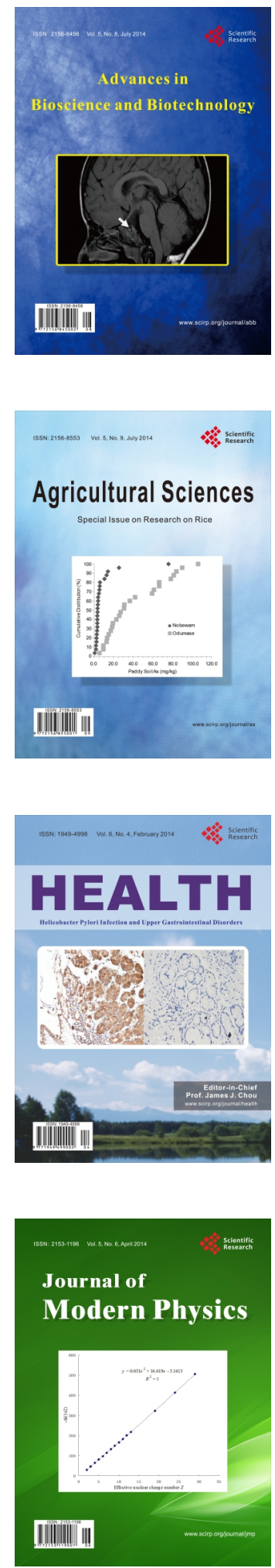
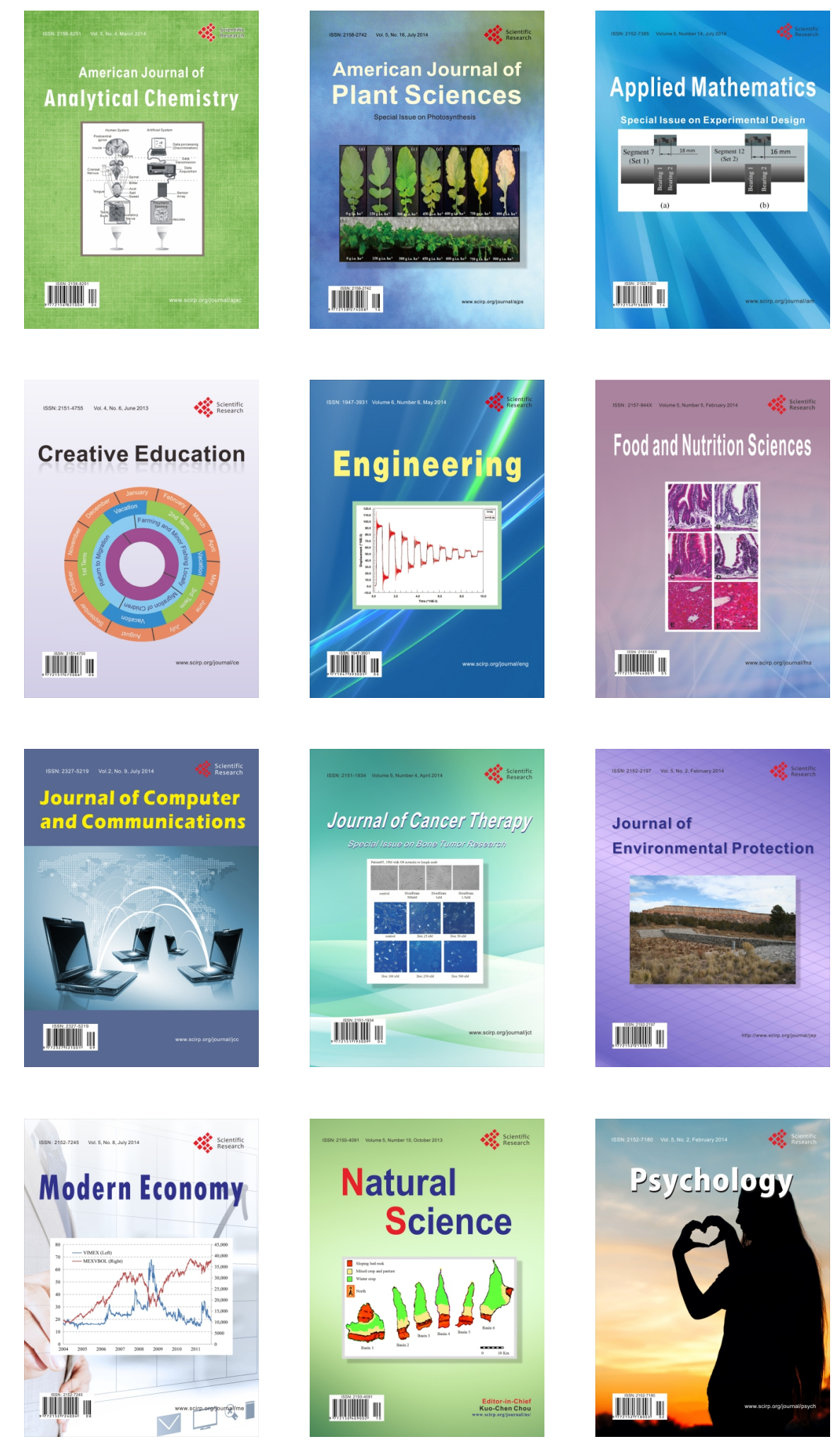